\title{
PERAN KELUARGA DAN KEBIJAKAN PEMERINTAH KOTA PALANGKA RAYA DALAM PENGELOLAAN SAMPAH RUMAH TANGGA
}

\author{
Dody Ariyantho Kusma Wijaya \\ UPT-MKU Universitas Palangka Raya \\ e-mail: doddyariantho@yahoo.co.id
}

\begin{abstract}
This research study the role of Family and Government Policy of Palangka Raya in Household Waste Managementin order to see whowas the most responsible for decisionmakers in the process of waste management in households, and examines the role of families in the process of waste management before disposal into the trash. Data collection was done through observation and interview on the studied variables. The research was conducted in the district of Pahandut, district of Jekan Raya and district of Sebangau Palangka Raya in April till June 2011. The Source of data or respondents in the research community is engaged in managing and disposing of garbage. The community is a society of each chosen houshold. Sampling was done purposively stratified. The results showed that the head of the family was instrumental in the process of garbage disposal. Garbage disposal decision makers is the father of $68.9 \%$ (31 respondents) and the mothers of $31,1 \%$ (14 respondents). In the waste management at household level was the comparison between wet waste and dry waste that is equal to $1 / 3$ most was $54 \%$ (7 respondents. This indicates that the household waste produced is a dry waste.
\end{abstract}

Keywords: dry waste, household waste, wet waste

\begin{abstract}
ABSTRAK
Penelitian ini bertujuan untuk mengetahui peran keluarga dan kebijakan pemerintah Kota Palangka Raya dalam pengelolaan sampah rumah tangga agar dapat melihat siapa yang paling berperan sebagai pengambil keputusan dalam proses pengelolaan sampah di dalam rumah tangga, serta mengkaji peranan keluarga dalam proses pengelolaan sampah sebelum dibuang ke tempat sampah. Pengumpulan data dilakukan melalui pengamatan atau observasi (observation) dan wawancara (interview) terhadap variabel yang diteliti. Penelitian ini dilaksanakan di Kecamatan Pahandut, Kecamatan Jekan Raya dan Kecamatan Sebangau Kota Palangka Raya pada bulan April hingga bulan Juni 2011. Sumber data atau responden dalam penelitian adalah masyarakat yang terlibat dalam kegiatan pengelolaan dan pembuangan sampah. Masyarakat yang dimaksud adalah masyarakat dari masing-masing rumah tangga terpilih. Pengambilan sampel dilakukan secara purposive berstrata. Hasil penelitian menunjukkan bahwa kepala keluarga sangat berperan dalam proses pembuangan sampah, pengambil keputusan pembuangan sampah adalah Bapak sebesar 68,9\% (31 responden) dan lbu sebesar 31,1\% (14 responden), Dalam pengelolaan sampah di tingkat rumah tangga ternyata perbandingan antara sampah basah dan sampah kering terbanyak adalah $1 / 3$ yaitu sebesar $54 \%$ (7 responden). Hal ini menunjukkan bahwa sampah rumah tangga yang dihasilkan adalah berupa sampah kering.
\end{abstract}

Kata kunci: sampah basah, sampah kering, sampah rumah tangga 
Pertambahan jumlah penduduk membawa dampak yang cukup signifikan terhadap berbagai sektor kehidupan, seperti adanya tuntutan peningkatan kemampuan daya tampung lapangan kerja, kapasitas daya dukung fasilitas publik dan ketersediaan sumber-sumber primer seperti pangan, sandang, dan papan yang memadai serta tuntutan untuk menggerakkan kegiatan ekonomi dalam rangka peningkatan kesejahteraan rakyat. Fakta empirik menunjukkan bahwa pertambahan jumlah penduduk yang terus meningkat akan meningkatkan konsumsi masyarakat dan hal ini akan mengakibatkan semakin bertambahnya volume sampah.

Berbagai upaya dan kebijakan Pemerintah Kota Palangka Raya dalam menjaga kebersihan dan menangani masalah sampah perkotaan, tentunya tidak hanya menjadi tanggung jawab Pemerintah Kota saja akan tetapi peran serta dan partisipasi masyarakat yang ada di Kota Palangka Raya juga sangat menentukan. Hal ini terlihat dengan dikeluarkannya Peraturan Daerah (Perda) Kota Palangka Raya Nomor 03 Tahun 2006 tentang Pengelolaan Kebersihan Lingkungan dan Pertamanan. Beberapa point penting dari Perda tersebut adalah kewajiban masyarakat untuk menjaga kebersihan lingkungan sekitarnya dan kewajiban membuang sampah ke TPS (Tempat Pembuangan Sampah) pada waktu yang sudah ditentukan yaitu mulai pukul 16.00 WIB sampai dengan pukul 03.00 WIB. Sedangkan untuk pemilik/badan usaha atau pemakai persil usaha yang menghasilkan sampah sebanyak $2,5 \mathrm{~m}^{3}$ atau lebih setiap hari wajib membuang sendiri sampah tersebut ke TPA (Tempat Pembuangan Akhir), kecuali ada permintaan bantuan ke Dinas Pasar dan Kebersihan Kota Palangka Raya.

Rumah tangga sebagai salah satu penghasil sampah terbesar, seperti data yang ditunjukkan oleh Dinas Pasar dan Kebersihan Kota Palangka Raya (2011) menyebutkan bahwa sampah domestik yang dihasilkan mencapai $550 \mathrm{~m}^{3}$ per hari. Untuk itu diperlukan program penanganan sampah yang baik dan haruslah berawal dari upaya penyadaran dan peningkatan partisipasi masyarakat, dalam hal ini rumah tangga untuk mengelola sampah yang dihasilkan. Semua sampah yang dihasilkan tersebut ditampung oleh 203 TPS yang tersebar di Kota Palangka Raya dan 1 TPA yang berlokasi di Jalan Tjilik Riwut Km.14 Palangka Raya (Dinas Pasar dan Kebersihan Kota Palangka Raya, 2011).

Penelitian ini bertujuan untuk mengetahui siapa saja yang berperan (bapak atau ibu) dalam pengambil keputusan pada proses pengelolaan sampah di dalam rumah tangga dan mengkaji peranan keluarga dalam proses pengelolaan sampah sebelum dibuang ke tempat sampah.

\section{METODE}

Pengambilan lokasi penelitian dilaksanakan dengan sengaja secara bertingkat atau multistage purposive sampling. Dari 5 Kecamatan yang ada di Kota Palangka Raya, dipilih 3 Kecamatan masing-masing: Kecamatan Pahandut, Kecamatan Jekan, dan Kecamatan Sabangau.

Alasan pemilihan 3 Kecamatan di Kota Palangka Raya di atas adalah Kota Palangka Raya merupakan kota yang sedang berkembang dengan jumlah penduduk yang memiliki tingkat pendidikan relatif tinggi dan bersifat heterogen, baik suku, agama, pendidikan, pendapatan dan pekerjaan. Dipilih 3 kecamatan di atas sebagai tempat penelitian juga karena lokasi tersebut mewakili pemukiman yang penghuninya bermata pencaharian sebagai PNS (Pegawai Negeri Sipil), pelaku usaha dan buruh serta keterwakilan sebagai daerah perkotaan dan daerah pinggiran.

Kegiatan penelitian ini berlangsung selama 3 bulan dan dilaksanakan sejakApril hingga Juni 2011. Bahan dan peralatan yang digunakan dalam penelitian ini terdiri dari perangkat instrumen penelitian, yaitu kuesioner dan pedoman wawancara. 
Penelitian ini dilaksanakan dengan metode survei. Dalam pelaksanaan penelitian ini pengumpulan data dilakukan melalui pengamatan atau observasi (observation) dan wawancara (interview) terhadap variabel yang diteliti. Wawancara akan dipandu dengan kuesioner dan pedoman wawancara. Jenis data yang diperlukan dalam penelitian ini terdiri atas data primer dan data sekunder. Data primer yang diperlukan dari responden tersebut dipilih dan dibatasi berdasarkan kesesuaiannya dengan pertanyaan-pertanyaan dasar dalam rencana penelitian yang keseluruhannya ditempatkan dalam kerangka pengelolaan sampah, seperti siapa pengambil keputusan pengelolaan sampah, tentang pandangan, tata cara dan teknologi, wawasan lingkungan yang berkelanjutan, lingkungan hidup, ekonomi dan sosial.

Data sekunder dikumpulkan dari laporan dan publikasi-publikasi yang diterbitkan oleh instansi yang berwenang, seperti: Dinas Pasar dan Kebersihan Kota Palangka Raya, Badan Pusat Statistik Kota Palangka Raya, Pemerintahan Desa, Dinas Tata Kota Palangka Raya, Sekretariat Daerah Kota Palangka Raya serta kepustakaan yang relevan dengan penelitian ini. Data yang diambil meliputi jumlah penduduk, jumlah TPS, armada truk sampah, dan kebijakan tentang pengelolaan sampah.

Berdasarkan sifat data sebagai suatu kumpulan berwujud angka, kemudian menjadi rangkaian kata-kata, maka untuk menganalisa data tersebut digunakan metode analisis deskriptif yang disajikan dalam bentuk tabel dan grafik. Dalam metode analisis deskriptif dilakukan melalui 2 tahapan kegiatan, yaitu: Penyajian data dibuat dalam bentuk tabel dan grafik. Semua jenis data digabungkan, disusun dalam bentuk yang padu, sehingga mudah untuk menarik kesimpulan. Menarik kesimpulan setelah kegiatan pengumpulan data dan penyajian data dilakukan, kemudian melakukan interpretasi data, seperti mencatat keteraturannya, pola-pola, penjelasan, sebab akibat dan proporsi. Penarikan kesimpulan dapat dirumuskan setelah menggabungkan informasi yang tersusun dalam suatu bentuk yang padu dan benar.

Sumber data atau responden dalam penelitian adalah masyarakat yang terlibat dalam kegiatan pengelolaan dan pembuangan sampah, yaitu masyarakat dari masing-masing Rukun Tetangga (RT) terpilih. Responden adalah para kepala keluarga, aparat desa atau pengurus Rukun Tetangga (RT), tokoh masyarakat dan pelaku dunia usaha. Pengambilan sampel dilakukan secara purposive berstrata berdasarkan peranannya dalam menghasilkan dan dalam pengelolaan sampah, yaitu diambil $15 \mathrm{KK}$ (kepala keluarga) pada setiap wilayah penelitian yang masing-masing terdiri atas $12 \mathrm{KK}$ dari rumah tangga, $1 \mathrm{KK}$ dari tokoh agama, $1 \mathrm{KK}$ dari tokoh masyarakat serta $1 \mathrm{KK}$ dari dunia usaha/pelaku bisnis. Karena ada 3 wilayah penelitian maka responden dalam penelitian ini berjumlah $3 \times 15 \mathrm{KK}=45 \mathrm{KK}$.

\section{HASIL DAN PEMBAHASAN}

Karakteristik Responden (Usia, Tingkat Pendidikan, dan Jenis Kelamin Responden)

Data yang didapatkan menunjukkan sebaran usia responden penelitian ini adalah $\leq 30$ tahun sebesar $4,4 \%$ ( 2 responden), 31-40 tahun sebesar 28,7\% (13 responden), $42-50$ tahun sebesar $39,9 \%$ (18 responden), $51-60$ tahun sebesar $17,7 \%$ (8 responden) dan $>60$ tahun sebesar $8,8 \%$ (4 responden). Untuk tingkat pendidikan responden rata-rata berpendidikan tinggi yaitu lulusan Sarjana sebesar 35,6\% (16 responden), Diploma sebesar 6,7\% (3 responden), SLTA sebesar 48,9\% (22 responden), SLTP sebesar 6,7\% (3 responden) dan SD/SR sebesar 2,2\% (1 responden). Untuk jenis kelamin responden didominasi oleh laki-laki dengan persentase sebesar $91,1 \%$ (41 responden) dan perempuan hanya $8,9 \%$ (4 responden). 


\section{Pengambil Keputusan dalam Proses Pengelolaan Sampah}

Dari hasil yang didapat terlihat bahwa kepala keluarga sebagai pengambil keputusan sangat berperan dalam proses pembuangan sampah di rumah tangga responden. Untuk proses pengambilan keputusan pembuangan sampah adalah bapak sebesar 68,9\% (31 responden) dan ibu sebesar $31,1 \%$ (14 responden). Hal ini menunjukkan posisi bapak sebagai kepala rumah tangga adalah penting dan strategis dalam pengelolaan sampah di tingkat rumah tangga (Gambar 1).

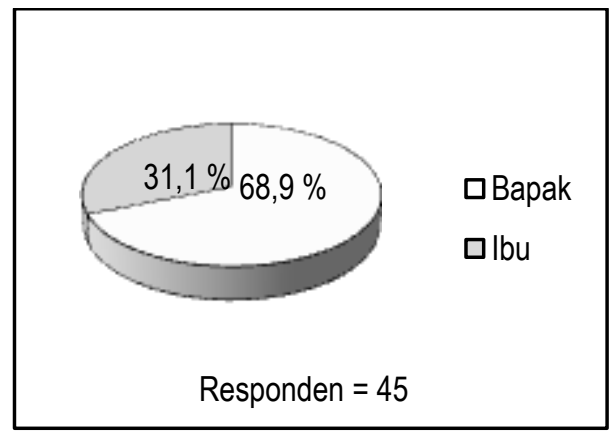

Gambar 1. Perbandingan yang mengarahkan/mengatur pembuangan sampah di rumah responden

\section{Peranan Keluarga dalam Proses Pengelolaan Sampah Rumah Tangga}

Dalam Peraturan Daerah Kota Palangka Raya No. 03 Tahun 2006 pada Bab II Pasal 3 (ayat 1-2), Pemerintah Daerah wajib mengadakan sarana dan prasarana kebersihan dan pertamanan berupa menyediakan tempat sampah di tempat-tempat umum dan jalan umum, menyediakan tempat penampungan sementara dan tempat pembuangan akhir, melaksanakan pengangkutan dari TPS ke TPA serta menyediakan petugas kebersihan dan peralatannya, kemudian bagi warga masyarakat wajib mengadakan sarana dan prasarana kebersihan dan pertamanan berupa membuat tempat sampah pada setiap persil, kendaraan darat maupun sungai serta melakukan pengangkutan sampah dari persil ke TPS dan transfer depo dan dilaksanakan dengan koordinasi RT/RW di wilayahnya masing-masing dan mengikuti petunjuk-petunjuk yang diberikan oleh walikota atau pejabat yang ditunjuk.

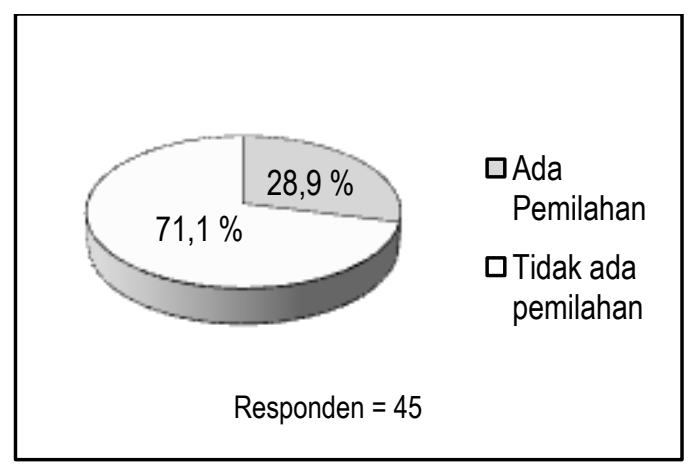

Gambar 2. Perbandingan antara responden yang melakukan pemilahan sampah dengan yang tidak melakukan pemilahan sampah 
Untuk proses pemilahan sampah antara sampah basah dengan sampah kering masih belum terlihat peranan kepala keluarga. Untuk pemilahan antara sampah basah dengan sampah kering $71,1 \%$ (32 responden) tidak melakukan pemilahan langsung terhadap sampah basah dan sampah kering, sedangkan yang melakukan pemilahan adalah 28,9\% (13 responden), seperti yang disajikan pada Gambar 2.

Dalam pengelolaan sampah di tingkat rumah tangga ternyata perbandingan antara sampah basah dan sampah kering terbanyak adalah $1 / 3$ yaitu sebesar $54 \%$ (7 responden). Hal ini menunjukkan bahwa sampah yang dominan dari sampah rumah tangga yang dihasilkan adalah berupa sampah kering (Gambar 3).

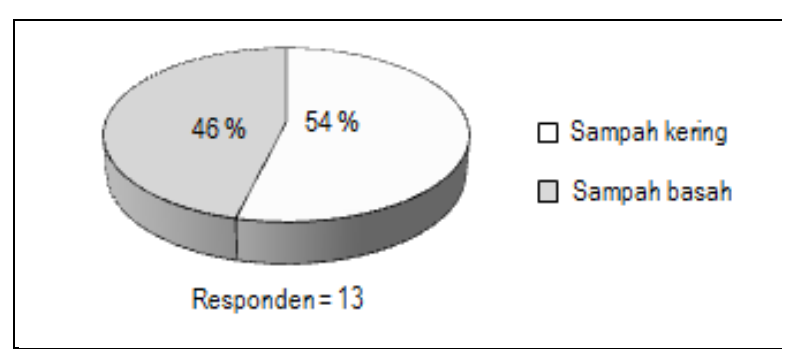

Gambar 3. Perbandingan sampah basah dengan sampah kering di rumah responden

Menurut Dinas Pasar dan Kebersihan Kota Palangka Raya rata-rata volume sampah yang dihasilkan penduduk Kota Palangka Raya adalah 2,49 liter/orang/hari. Berdasarkan pengamatan dalam penelitian ini ternyata sampah yang dihasilkan hanya berupa bungkus makanan. Hal ini menunjukkan bahwa responden mempunyai kebiasaan membeli makanan yang sudah masak. Semua responden (100\%) setuju pada akhirnya nanti harus dilakukan pemilahan sampah antara sampah basah dengan sampah kering, seperti yang disajikan pada Gambar 4.

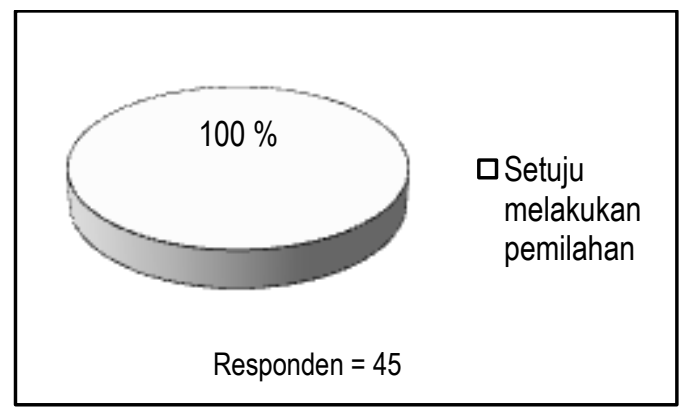

Gambar 4. Persepsi responden dalam pemilahan sampah

Untuk tempat penampungan sementara sampah sebelum dibuang ke TPS (Tempat Pembuangan Sementara), responden menyatakan bahwa yang membuang sampah ke tempat sampah sementara misalnya dalam kotak kardus atau tempat sampah kecil sebesar 33,3\% (15 responden), sedangkan yang membuang sampah sementara menggunakan kantong plastik sebesar $66,7 \%$ (30 responden) seperti yang disajikan pada Gambar 5. 


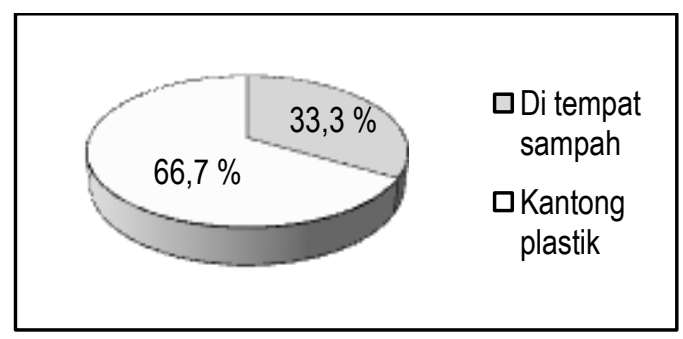

Responden $=45$

Gambar 5. Perbandingan tempat pembuangan sementara responden sebelum sampah dibuang ke TPS

Sampah yang terkumpul baik di kantong plastik maupun bak sampah sementara dibuang keluar rumah oleh responden ada yang melalui mekanisme penimbunan yaitu dibuang dalam lubang yang dibuat sendiri sebesar 2,2\% (1 responden), dikarenakan tempat tinggal responden cukup jauh dari tempat pembuangan sementara sehingga responden enggan untuk membuang sampah ke tempat pembuangan sementara dan membuat lubang sampah sendiri untuk menampung sampah, sedangkan yang membuang ke tempat pembuangan sementara sebesar $97,8 \%$ (44 responden). Hasil penelitian ini menunjukkan bahwa para responden memiliki kesadaran yang sangat tinggi untuk tidak membuang sampah sembarangan seperti yang disajikan pada Gambar 6 .

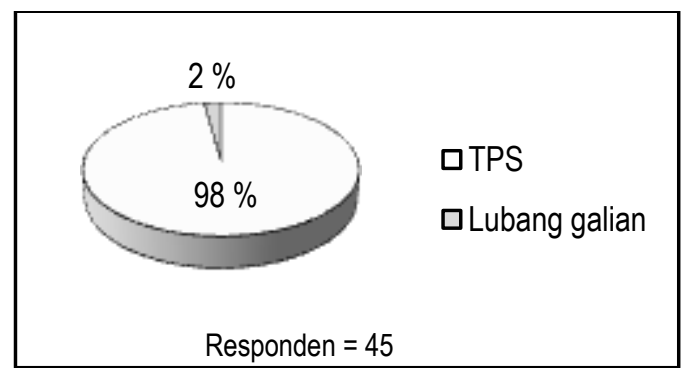

Gambar 6. Perbandingan cara pembuangan sampah dari rumah responden

Dengan adanya pengaturan pengelolaan sampah di tingkat rumah tangga diharapkan nantinya tidak akan ada lagi keluhan tentang gangguan akibat dari pembuangan sampah. Ini terlihat bahwa 60\% (27 responden) merasa terganggu akibat bau yang ditimbulkan (Gambar 7).

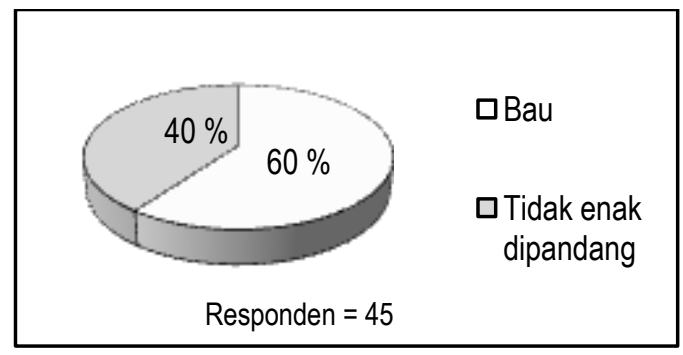

Gambar 7. Gangguan akibat sampah 
Undang-undang Nomor 18 Tahun 2008 tentang Pengelolaan Sampah mengatakan setiap orang dalam pengelolaan sampah rumah tangga dan sampah sejenis rumah tangga wajib mengurangi dan menangani sampah dengan cara berwawasan lingkungan. Untuk itu pengelolaan sampah di tingkat rumah tangga sangat mendesak untuk dilaksanakan. Pengelolaan sampah rumah tangga dan sampah sejenis rumah tangga terdiri atas: pengurangan sampah dan penanganan sampah, sedangkan pengurangan sampah adalah pembatasan timbunan sampah, pendauran ulang sampah, dan/atau pemanfaatan kembali sampah melalui proses reduce, reuse, dan recycle.

\section{Kebijakan Pemerintah Kota Palangka Raya dalam Pengelolaan Sampah}

Pemerintah Kota Palangka Raya memiliki kebijakan umum tentang pengelolaan sampah yang dituangkan dalam Peraturan Daerah Nomor 03 Tahun 2006 tentang Pengelolaan Kebersihan Lingkungan dan Pertamanan di Kota Palangka Raya. Dalam peraturan tersebut terdapat beberapa point penting, seperti kewajiban masyarakat untuk menjaga kebersihan lingkungan sekitarnya dan kewajiban membuang sampah ke TPS pada waktu yang sudah ditentukan yaitu mulai pukul 16.00 WIB sampai dengan pukul 03.00 WIB.

Selama ini dengan fasilitas yang dimiliki oleh Pemerintah Kota Palangka Raya dalam mengelola sampah, masih banyak sampah yang tidak terangkut dari TPS ke TPA. Padahal kalau dihitung jumlah TPS yang disediakan sebenarnya belum mencukupi untuk memenuhi kebutuhan Kota Palangka Raya. Dari daya tampung TPS yang masih kurang, Pemerintah Kota Palangka Raya seharusnya menambah jumlah TPS menjadi 225 buah TPS dari yang sebelumnya berjumlah 203 buah TPS, sehingga tidak ada lagi sampah yang masih tersisa di TPS ketika pengangkutan sampah ke TPA. Untuk angkutan truk yang tersedia saat ini masih kurang untuk dapat memenuhi kebutuhan pengangkutan sampah dari TPS ke TPA. Dengan 15 unit truk yang tersedia berarti hanya sekitar 90 $\mathrm{m}^{3}$ sampah dapat terangkut untuk sekali angkut, sehingga untuk bisa mengangkut habis semua sampah dari TPS ke TPA memerlukan 7 kali angkut, idealnya maksimal 2 kali angkut saja sehingga sampah yang ada tidak terlalu siang untuk diangkut. Jumlah truk yang ideal adalah sekitar 47 unit truk sehingga bisa 2 kali angkut. Terjadinya penumpukan sampah di TPS selain dikarenakan kurangnya fasilitas angkut juga dikarenakan sikap masyarakat yang masih menganggap masalah sampah adalah urusan pemerintah. Selain itu pola pembuangan sampah masyarakat yang tidak tertib jam pembuangan sehingga membuat TPS yang sudah diangkut pagi oleh petugas menjadi berisi lagi ketika siang harinya.

Tabel 1. Sarana dan Prasarana pada Dinas Pasar dan Kebersihan Kota Palangka Raya

\begin{tabular}{lrl}
\hline Jenis Sarana & Jumlah & Keterangan \\
\hline TPA (Tempat Pembuangan Akhir) & 1 buah & Luas 10 ha \\
TPS (Tempat Pembuangan Sementara) & 203 buah & Rata-rata kapasitas $2,5 \mathrm{~m}^{3}$ \\
Dump Truck Sampah & 11 buah & $180 \mathrm{~m}^{3} /$ hari \\
Arm Roll Truck & 4 buah & $120 \mathrm{~m}^{3} /$ hari \\
Excavator & 1 buah & Rusak \\
Buldozer & 1 buah & \\
Petugas & 250 orang & Petugas Angkutan, penyapu, \\
& & petugas taman \\
\hline
\end{tabular}

Sumber : DPK Kota Palangka Raya (2011) 
Pemerintah Kota Palangka Raya dalam implementasi pengelolaan sampah masih bersifat pada proses angkut sampah dari TPS ke TPA dan tumpuk di TPA. Selain tidak terlalu efektif, sistem ini memerlukan biaya yang sangat besar untuk mobilisasi pasukan kebersihan beserta armadanya. Fasilitas TPS yang ada sekarang ini masih menggabungkan antara sampah basah dengan sampah kering sehingga akan sia-sia usaha pemisahan sampah yang dilakukan oleh setiap rumah tangga karena ketika dibuang ke tempat sampah sementara akan tercampur lagi. Dengan peran serta masyarakat, volume sampah yang harus ditangani oleh pemerintah akan jauh berkurang. Dengan demikian lingkungan menjadi bersih, banjir akibat sungai yang dipenuhi sampah tidak terjadi lagi, dan penyakit karena timbunan sampah jauh berkurang.

Kedepannya Pemerintah Kota Palangka Raya harus memiliki peraturan daerah yang memang khusus mengatur tentang sampah dengan penerapan $3 \mathrm{R}$ (reduce, reuse,dan recycle), tidak tergabung seperti peraturan yang ada saat ini. Peraturan daerah itu nantinya akan mengatur tentang sampah rumah tangga sesuai dengan Undang-undang Nomor 18 Tahun 2008 tentang Pengelolaan Sampah. Peraturan daerah itu juga mengatur tentang pemilahan sampah basah dengan sampah kering dilanjutkan dengan pengelolaan sampah seperti pengomposan, daur ulang, dan lain sebagainya.

\section{SIMPULAN}

Untuk proses pengambilan keputusan pembuangan sampah rumah tangga dilakukan oleh bapak sebesar $68,9 \%$ (31 responden) dan ibu sebesar 31,1\% (14 responden). Hal ini menunjukkan posisi bapak dan ibu adalah penting dan strategis dalam pengelolaan sampah di tingkat rumah tangga.Untuk tempat penampungan sementara sampah sebelum dibuang ke TPS yang membuang ketempat sampah sementara dengan menggunakan kotak kardus atau tempat sampah kecil sebesar $33,3 \%$ (15 responden), sedangkan yang membuang sampah sementara ke kantong plastik sebesar $66,7 \%$ (30 responden).

\section{SARAN}

Hendaknya ada peraturan daerah yang khusus mengatur tentang sampah terutama sampah rumah tangga termasuk didalamnya tentang pemilahan dan pemanfaatan sampah untuk hal yang berwawasan lingkungan dan ekonomi seperti pemanfaatan sampah untuk kompos, pemberian punishment bagi pelanggaran regulasi pengelolaan sampah dan reward bagi yang taat terhadap regulasi pengelolaan sampah.Kepada Pemerintah Kota Palangka Raya dalam hal ini Dinas Pasar dan Kebersihan kiranya perlu menambah sarana dan prasarana seperti TPS dan armada angkutan karena sarana yang ada saat ini tidak mencukupi.

\section{REFERENSI}

Dinas Pasar dan Kebersihan (DPK) Kota Palangka Raya. (2011). Pemerintah Kota Palangka Raya. Palangka Raya.(Tidak Dipublikasikan).

Sekretariat Daerah Kota Palangka Raya. (2011). Peraturan Daerah Nomor 03 Tahun 2006. Tentang Pengelolaan Kebersihan Lingkungan dan Pertamanan. Lembaran Daerah Kota Palangka Raya Tahun 2006 Nomor 03. Palangka Raya. (Tidak Dipublikasikan).

Sekretariat Negara Republik Indonesia. (2008). Undang-Undang Nomor 18 Tahun 2008 Tentang Pengelolaan Sampah. Jakarta. 